\title{
PENGEMBANGAN PROSES PEMBUATAN BERAS TIRUAN BERBASIS UMBI LOKAL DENGAN MEMANFAATKAN EKSTRUDER ULIR TUNGGAL
}

Oleh :

\author{
AGUS SANTOSO, YOSSI WIBISONO *), dan HERI WARSITO **)
}

\begin{abstract}
ABSTRAK
Salah satu permasalahan dalam rangka diversifikasi pangan pokok adalah kebiasaan masyarakat mengkonsumsi beras. Pengembangan beras tiruan dari bahan-bahan lokal seperti: jagung, singkong dan pati sagu belum dikembangkan secara komersial karena rumitnya proses pengolahan. Pemasakan ekstrusi merupakan suatu metode yang dapat menyederhanakan proses pengadukkan, pencetakan dan pemasakan menjadi satu tahapan proses. Untuk dapat diaplikasikan pada industri kecil di negara berkembang perlu dikembangkan ekstruder mesin kecil sederhana.

Tujuan dari penelitian ini adalah pengembangan ekstruder mesin kecil sederhana untuk pembuatan beras tiruan yang memiliki kualitas yang baik serta dapat memberikan margin keuntungan yang memadai bagi industri kecil. Penelitian disusun menjadi beberapa tahapan yaitu: (1) Mendesain ulir dan die ekstruder; (2) Menguji performa ekstruder dengan penyesuaian kecepatan bahan masuk, kecepatan putar ulir serta suhu pemasakan; (3) Mengevaluasi karakter produk yang dihasilkan dari segi mutu dan penerimaan konsumen; (4) Melakukan studi kelayakan ekonomi.

Hasil penelitian yang diperoleh dari tahun pertama adalah produksi ulir dan ekstruder teroptimalisasi dengan single screw bersudut 7,5 derajat yang memghasilkan tekanan aliran fluida sebesar 1,2038339 x 10 pangkat $17 \mathrm{~Pa}$, kecepatan ulir $450 \mathrm{rpm}$ dengan teknik cold extrusion yang mampu menghasilkan beras tiruan optimal dengan penggunaan formulasi bahan baku $30 \%$ tepung jagung dan $70 \%$ tepung mocaf yang menghasilkan pengukuran warna dengan nilai $\mathrm{L} 76,26$, $a+5,35$ dan $b+31,39$, kadar protein $9,73 \%$; kadar serat 5\%; kadar air 9\%; kadar abu 0,52\%; kadar lemak 1,12\%; dan densitas kamba 0,58 g/ml. Bakteri yang digunakan untuk Biologically Modified Cassava Flour adalah bakteri hasil pengembangan dari tim peneliti dengan strain baru L. plantarum polije 15420. Baik rancangan desain ulir, formulasi serta metode pembuatan beras tiruan maupun bakteri telah diajukan untuk proses drafting paten.
\end{abstract}

Kata kunci: beras tiruan, tepung jagung, mocaf, ekstruder ulir tunggal

\section{PENDAHULUAN}

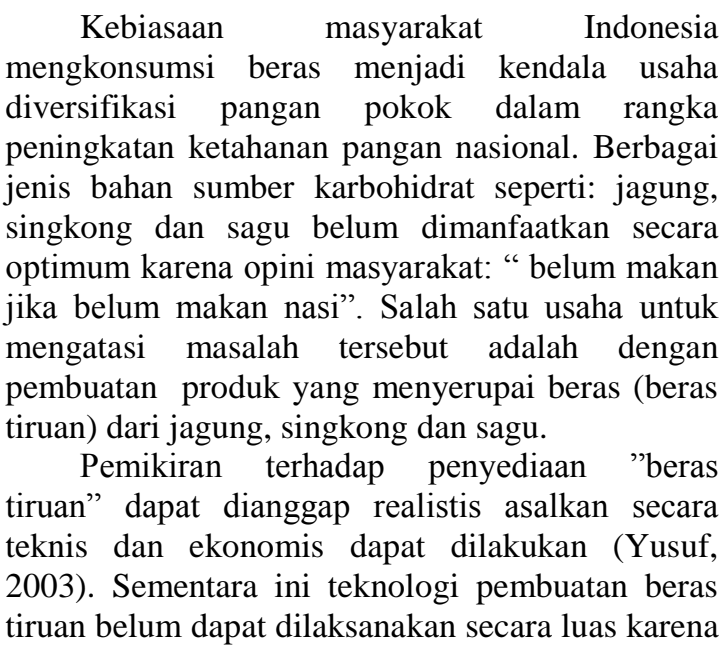

proses pembuatannya yang rumit. Untuk mengatasi masalah tersebut, teknologi yang dapat dikembangkan adalah ekstruksi. Dalam proses ekstruksi ada beberapa tahapan yang bisa dicakup yaitu: pencampuran, pengadukan, pencetakan dan pemasakan (Guy, 2003.). Konfigurasi ulir pada ekstruder mempengaruhi besarnya shear stress serta mempengaruhi kualitas produk (Bjorck and Asp, 1983). Nilai shear stress dan tekanan pada die yang tinggi akan mengakibatkan produk ekstruksi terekspansi (Guy, 2003). Dalam pembuatan beras tiruan hal tersebut tidak dikehendaki. Untuk pembuatan beras tiruan diperlukan modifikasi terhadap mesin ekstruder yaitu: modifikasi desain ulir, die dan suhu pemasakan.

Adopsi pemasakan ekstrusi di negara berkembang masih sangat terbatas karena unit industri yang menghasilkan pangan terekstrusi 
Agus S,Yossi W, dan Heri Warsito, Pengembangan Proses Pembuatan Beras Tiruan Berbasis Umbi Lokal Dengan Memanfaatkan Ekstruder Ulir Tunggal

umumnya dari industri non-pemerintah dengan skala international. Hal tersebut disebabkan karena umumnya ekstruder di desain untuk produksi skala besar, yang membutuhkan modal besar dan kemampuan teknik yang tinggi. Pengembangan mesin kecil sederhana sangat sesuai untuk kondisi negara berkembang dan pengaplikasiannya untuk pengolahan beras tiruan diharapkan mampu mengembangkan industri kecil serta dapat meningkatkan diversifikasi pangan. Mouquet et al.(2003), telah mengaplikasikan ekstruder mesin kecil sederhana untuk pembuatan bubur instan, dimana mesin tersebut telah dimanfaatkan di Vietnam.

\section{METODOLOGI}

\section{Penelitian Tahap I}

\section{Mendesain Ulir dan Die Ekstruder}

Tujuan dari tahapan ini adalah untuk menentukan desain ulir dan die yang akan menghasilkan butiran-butiran berbentuk beras dengan sifat-sifat optimum. Untuk itu digunakan simulasi komputer dengan menggunakan pemrograman komputer CATIA dan ANSYS. Beberapa model ulir dan die diujikan dalam simulasi komputer tersebut. Akhirnya diperoleh empat pasang ulir dan die yang akan diujikan dalam tahap eksperimental.

Pada tahap eksperimental parameter yang diamati adalah:

1. Shanon enthrophy (Shanon, 1948): untuk mengukur tingkat pengadukan dari ulir ekstruder.

2. Rendemen (\% beras yang dihasilkan): mengukur kemampuan ulir dan die dalam mencetak beras.

Data yang diperoleh diuji dengan Rancangan Acak Kelompok 1 (satu) faktor dan dilanjutkan dengan uji beda nyata terkecil. Ulir dan die yang paling optimum dipilih dengan uji efektifitas (Galmo, 1984).

\section{Pembuatan Mesin Ekstruder}

Mesin ekstruder ini dibuat berdasarkan alat ekstruder yang telah dirancang sebelumnya. Ekstruder tersebut menggunakan ulir tunggal yang sederhana. Power dari motor penggeraknya 10,5 $\mathrm{kW}$, dimana panjang barrel, rasio panjang/diameternya serta bentuk dan ukuran disesuaikan dari penelitian tahap sebelum, dengan diamater ulir dan sudut kemiringannya disesuaikan dari penelitian tahap sebelumnya. Untuk memastikan keteraturan kecepatan bahan masuk, ekstruder dilengkapi dengan feeding screw yang dapat mengatur kecepatan bahan masuk dari 5 hingga $39 \mathrm{~kg} / \mathrm{jam}$.
Luaran dari penelitian penelitian tahap ini adalah mesin ekstruder yang dapat digunakan dalam pembuatan beras tiruan.

\section{Pengujian sifat-sifat beras tiruan yang dihasilkan}

Parameter yang diamati dalam penelitian ini adalah:

- Analisa proksimat (AOAC, 1995)

- Perbandingan sifat dengan beras biasa

\section{HASIL DAN PEMBAHASAN \\ Karakteristik Bahan Baku}

Perbedaan antara hasil analisa awal untuk bahan baku dengan hasil rujukan dari literatur disebabkan oleh perbedaan varietas, umur panen dan iklim. Kadar pati resisten yang berbeda dengan rujukan pada literatur diduga disebabkan adanya proses pengolahan dan vaietas bahan baku yang digunakan. Hasil tersebut telah ditunjukkan pada Tabel 1 berikut.

Tabel 1 Analisa Kimia Bahan Baku Jagung, Mocaf dan Ubi Kayu

\begin{tabular}{|c|c|c|c|c|c|c|}
\hline \multirow{2}{*}{ Parameter } & \multicolumn{2}{|c|}{ Jagung } & \multicolumn{2}{|c|}{ Mocaf } & \multicolumn{2}{|c|}{ Ubi Kayu } \\
\hline & $*$ & $* *$ & $*$ & *** & $*$ & $* *$ \\
\hline Air (\%) & $\begin{array}{l}15,1 \\
7\end{array}$ & 13,00 & $\begin{array}{l}68,7 \\
2\end{array}$ & 64,00 & $\begin{array}{l}64,6 \\
4\end{array}$ & $\begin{array}{l}62,4 \\
0\end{array}$ \\
\hline Abu (\%) & 1,70 & 1,40 & 1,05 & - & 0,26 & 1,30 \\
\hline Lemak $(\%)$ & 4,14 & 4,00 & 0,10 & 0,10 & 0,40 & 0,30 \\
\hline Protein $(\%)$ & 8,93 & 10,00 & 2,45 & 2,00 & 1,23 & 1,20 \\
\hline Pati (\%) & $\begin{array}{l}66,5 \\
5\end{array}$ & 61,00 & $\begin{array}{l}20,6 \\
3\end{array}$ & 19,10 & $\begin{array}{l}30,7 \\
9\end{array}$ & $\begin{array}{l}34,0 \\
0\end{array}$ \\
\hline $\begin{array}{l}\text { Amilosa } \\
(\%)\end{array}$ & $\begin{array}{l}19,5 \\
7\end{array}$ & 17,08 & 7,05 & 4,01 & 7,02 & 5,78 \\
\hline $\begin{array}{l}\text { Amilopekti } \\
\mathrm{n}(\%)\end{array}$ & $\begin{array}{l}46,9 \\
8\end{array}$ & 43,92 & $\begin{array}{l}13,5 \\
8\end{array}$ & 15,09 & $\begin{array}{l}23,7 \\
7\end{array}$ & $\begin{array}{l}28,2 \\
2\end{array}$ \\
\hline Rasio & $\begin{array}{l}29: 7 \\
1\end{array}$ & $28: 72$ & $\begin{array}{l}34: 6 \\
6\end{array}$ & $21: 79$ & $\begin{array}{l}23: 7 \\
7\end{array}$ & $\begin{array}{l}17: 8 \\
3\end{array}$ \\
\hline $\mathrm{Ca}(\%)$ & 0,06 & 0,03 & 0,02 & 0,01 & 0,02 & 0,03 \\
\hline $\begin{array}{l}\text { Pati } \\
\text { Resisten }\end{array}$ & 6,62 & $\begin{array}{l}>15,0 \\
0\end{array}$ & 6,30 & $\begin{array}{l}>15,0 \\
0\end{array}$ & 6,01 & $\begin{array}{l}11,5 \\
0\end{array}$ \\
\hline
\end{tabular}

Keterangan: * : Hasil Analisa

$$
\text { **: Literatur }
$$

Kecenderungan tersebut juga terjadi pada kadar protein pada ubi kayu hasil proses fermentasi (mocaf). Hal ini disebabkan, selain karena kadar protein pada bahan baku ubi kayu yang memang rendah dan juga tanpa adanya perikarp pelindung, menyebabkan sebagian protein dapat meningkat kelarutannya pada $\mathrm{pH}$ cenderung basa (menjauhi titik isoelektris), akibat perendaman dalam basa. Kadar pati resisten tertinggi justru diperoleh dari pati jagung. Jagung memiliki kadar amilosa yang paling tinggi dan mudah teretrogradasi, dengan pola peningkatan retrogradasi seiring dengan tingginya amilosa. Granula pati yang kaya akan amilosa dapat mengkristal lebih besar disebabkan oleh intensifnya ikatan hidrogen yang berakibat tidak 
mengembang atau mengalami gelatinisasi sempurna pada waktu pemasakan sehingga tercerna lebih lambat.

Pati jagung tidak mengalami gelatinisasi sempurna ketika pemanasan seperti pada ubi kayu, yang diduga mengakibatkan kurangnya daya cerna. Disisi lain, kandungan fosfor pada mocaf diduga berperan sebagai gugus ester-fosfat pada molekul amilopektin, menyebabkan bermuatan negatif yang menghasilkan gaya tolak menolak Coulomb yang mungkin memberikan kontribusi pengembangan granula pati mocaf. Sifat yang berbeda dari ketiga bahan akan memberikan karakteristik komposisi yang harus ideal untuk bahan baku pembuatan beras tiruan.

Ekstrusi merupakan salah satu tahapan proses yang banyak digunakan dalam industri. Proses ekstrusi dapat dilakukan dengan menggunakan single screw ataupun double screw. Dalam penelitian ini dikembangkan single screw karena geometrinya yang lebih sederhana dan lebih banyak diaplikasikan oleh industri pangan. Pada proses ekstrusi akan dihasilkan tegangan geser yang akan merubah bentuk adonan/bahan sehingga tegangan geser merupakan parameter penting pada proses ekstrusi. Selain itu kecepatan aliran akan menentukan besarnya gradien tekanan, profil suhu, tegangan geser (shear stress) dan residence time.

Pendekatan analitis pada desain ekstruder mempunyai beberapa keterbatasan karena sangat sulit untuk menganalisa aliran pada bentuk ekstruder yang rumit. Pendekatan yang lebih baik untuk menganalisa pengaduk yang rumit tersebut adalah dengan menggunakan model matematis dan simulasi komputer. FLUENT adalah salah satu jenis program CFD yang menggunakan pola metode volume sehingga semua fungsi yang dibutuhkan untuk menghitung suatu solusi dapat ditampilkan dan diakses pada FLUENT melalui menu yang interaktif.

Dari hasil simulasi menggunakan software FLUENT didapatkan nilai kecepatan aliran fluida rata-rata yang terbesar terjadi pada screw dengan sudut 2,5 derajat yaitu sebesar $0,26417857 \mathrm{~m} / \mathrm{s}$ sedangkan untuk sudut 5 derajat dan 7,5 derajat sebesar 0,2649498 $\mathrm{m} / \mathrm{s}$ dan $0,2649498 \mathrm{~m} / \mathrm{s}$. Sedangkan untuk tekanan total terbesar dihasilkan pada ekstruder dengan screw sudut 2,5 derajat yaitu sebesar 1,2219334 x 10 pangkat $17 \mathrm{~Pa}$, sedangkan untuk screw sudut 5 derajat dan sudut 7,5 derajat sebesar 1,2038339 x 10 pangkat $17 \mathrm{~Pa}$ dan 1,2038339 x 10 pangkat 17 $\mathrm{Pa}$. Untuk nilai tegangan geser pada partikel bahan, Semakin kecil sudut kemiringan pada ulir ekstruder maka tegangan geser yang dihasilkan pada partikel bahan akan semakin besar. Hal ini terjadi karena kenaikan dari viskositas bahan mempunyai presentasi yang paling besar pada screw dengan sudut kemiringan ulir yang semakin kecil. Proses ekstruksi pada beras tiruan menggunakan kecepatan ulir optimal yaitu 450 rpm dan pembuatan beras tiruan yang dikembangkan oleh gabungan peneliti dari tim Politeknik Negeri Jember dengan tim peneliti dari Universitas Jember adalah menggunakan teknik cold extrusion dengan penggunaan suhu $65^{\circ} \mathrm{C}$.

Ulir untuk beras tiruan yang telah dihasilkan oleh tim peneliti dapat dilihat pada Gambar 1 berikut. Optimalisasi ulir telah dilakukan dengan dengan perbedaan Compression Ratio $(1,5 ; 2,5 ; 3,5)$. Alat dasar (diluar ekstruder dan ulir) didesain dengan konsep portable. Desain alat lengkap masih akan dituangkan dalam konsep draft paten desain.

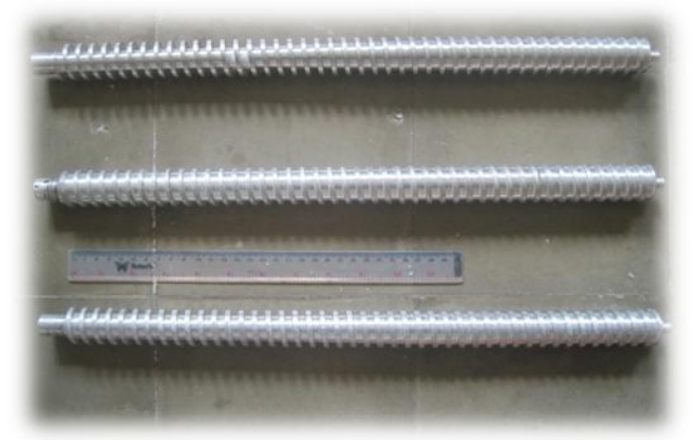

Gambar 1. Ulir yang dibuat dengan perbedaan compression ratio $(1,5 ; 2,5 ; 3,5)$

Suhu optimal yang digunakan pada proses ekstrusi adalah $65^{\circ} \mathrm{C}$ di semua bagian (feed, compressing dan metering) dengan kecepatan yang digunakan antara lain kecepatan auger $18 \mathrm{~Hz}$, screw $11 \mathrm{~Hz}$ dan cutter $55,5 \mathrm{~Hz}$. Kadar air masuk (feed) optimal 50\%, karena hasil kajian awal bahwa kadar air yang relatif tinggi akan mencegah terjadinya viscous dissipation yang akan menyebabkan kenaikan tenakan, sehingga tidak terjadi pengembangan produk. Hasil cetakan melalui die kemudian dilakukan proses pengeringan dengan dryer yang hasil kajian penelitian awal, optimal digunakan pada suhu $65^{\circ} \mathrm{C}$ selama 3 jam, hingga produk kering.

Penelitian tahap awal (uji coba proses) telah menggunakan suhu proses yang lebih rendah dibandingkan dengan suhu gelatinisasi, ternyata menghasilkan beras tiruan yang terkondisi rapuh dan tidak dapat diolah menjadi nasi. Selain itu hasil kajian awal telah memberikan data bahwa bobot per butir dari beras tiruan ditentukan pada saat pencetakan dengan ekstruder, dengan parameter yang paling berpengaruh adalah kecepatan screw dan kecepatan cutter. 
Agus S,Yossi W, dan Heri Warsito, Pengembangan Proses Pembuatan Beras Tiruan Berbasis Umbi Lokal Dengan Memanfaatkan Ekstruder Ulir Tunggal

\section{Produk Beras Tiruan}

Bahan dasar yang digunakan untuk beras tiruan adalah mocaf ubi kayu yang pada awalnya ditepungkan dengan tingkat ayakan tertentu dan dihomogenisasi, kemudian dikukus dan dikeringkan. Prosedur yang digunakan sedang diajukan dalam bentuk draft paten melalui proposal HAKI yang didanai oleh Dikti dan Lembaga Penelitian Universitas Jember. Hasil penelitian awal menunjukkan bahwa perbandingan jumlah pati dan tepung pada pembuatan beras tiruan yang paling optimal adalah dengan menggunakan $30 \%$ tepung jagung dan ditambah dengan $70 \%$ tepung mocaf. Pada penelitian pendahuluan juga menghasilkan informasi awal bahwa untuk proses optimalisasi, tidak dapat digunakan hanya satu tepung melainkan setidaknya dua jenis tepung pada tiap formulasi yaitu tepung jagung dan tepung substitusi (tepung mocaf) dengan perbandingan optimal 5:4.

Hasil produk beras tiruan dapat dilihat pada Gambar 2 dan setelah dilakukan proses pemasakan (menanak) dalam waktu 2 menit, hasil produk beras tiruan dapat dilihat pada Gambar 3 . Sekitar sembilan orang panelis tidak terlatih (konsumen pujasera kantin Teknologi Pertanian Universitas Jember) memberikan skor 4 (rentang skor 1 hingga 6) untuk uji kesukaan rasa, namun masih memberikan rata-rata skor 2 (rentang skor 1 hingga 6) untuk uji kesukaan warna dan kenampakan. Hal ini disebabkan hasil pengukuran warna beras tiruan dengan alat Chromameter ternyata menghasilkan pengukuran dengan nilai $\mathrm{L}$ 76,26 , a+5,35 dan $b+31,39$, sehingga warna beras tiruan berada pada kisaran warna merah kecoklatan. Sedangkan mutu tanak ditentukan berdasarkan sifat fisikomikia seperti suhu gelatinisasi, pengembangan volume, daya serap air, viscositas pasta awal serta konsistensi gel.

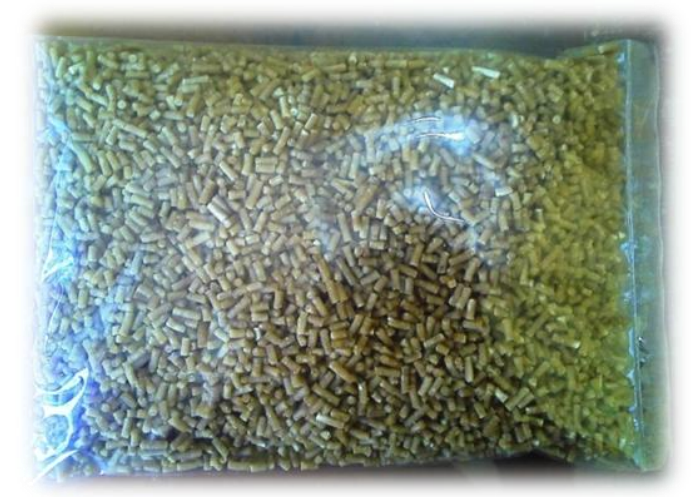

Gambar 2 Beras tiruan yang telah dihasilkan oleh tim peneliti dari Politeknik Negeri Jember dan Universitas Jember

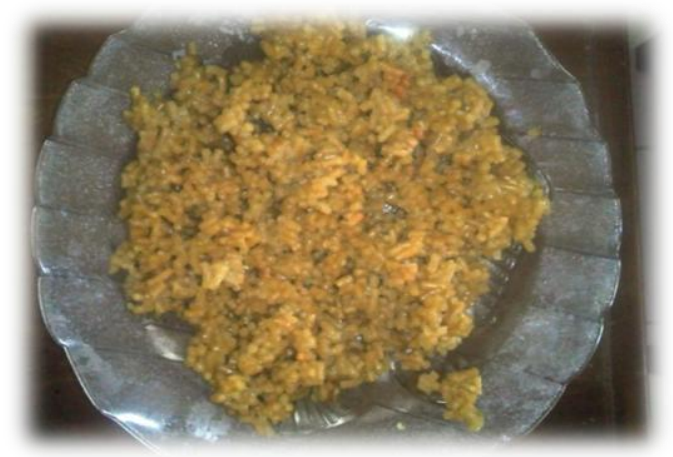

Gambar 3 Hasil nasi yang ditanak dari beras tiruan (uji organoleptik)

Teknik pembuatan mocaf yang dikembangkan tim peneliti adalah dengan teknik Biologically Modified Cassava Flour dan disingkat dengan BMCF. Penggunaan starter mocaf yang dikembangkan yaitu memerlukan $1,5 \mathrm{~kg} \mathrm{BMCF}$ untuk rendaman ubi kayu dengan wadah $1 \mathrm{~m}^{3}$ dan ditiriskan dengan mesin press. Pada proses pembuatan $1 \mathrm{~kg}$ mocaf diperlukan 3,5 kg singkong serta memerlukan waktu sekitar 1 jam untuk bahan singkong dalam wadah $1 \mathrm{~m}^{3}$. Kajian yang didapatkan dari penelitian awal menunjukkan bahwa saringan yang digunakan yaitu sebesar 60 mesh dapat menghasilkan butiran tepung yang paling optimal. Saat ini teknik pembuatan mocaf dengan teknik BMCF sedang dikembangkan untuk keperluan paten, karena dengan prosedur yang dilakukan ternyata tidak akan memberikan kondisi yang sesuai bagi kontaminan jamur, meskipun masih tetap menggunakan metode kering yang hampir sama seperti yang dilakukan di Sentra Petani Mocaf di Trenggalek.

Hal yang menarik adalah pembuatan mocaf yang sedang dikembangkan adalah menggunakan strain baru dari bakteri asam laktat, yaitu: L. plantarum polije: 15420. Polije adalah dingkatan dari Politeknik Negeri Jember. Bakteri ini merupakan pengembangan dari paten dan didaftarkan ke Kementrian Hukum dan HAM dengan nomer pendaftaran: 050.0226A oleh Pusat Penelitian dan Pengabdian (P3M) Politeknik Negeri Jember. Bakteri L. plantarum polije: 15420 hasil diverifikasi dari salah satu laboratorium di Universitas Brawijaya Malang dan Laboratorium TDC Unair Surabaya, ternyata disamping mempunyai kemampuan menghasilkan enzim pektinolitik yang dapat menghancurkan dinding sel bahan sehingga terjadi liberasi granula pati, juga mampu menghasilkan nisin yang merupakan antimikroba sehingga tepung mocaf yang dihasikan memiliki daya simpan yang lebih baik dibandingkan dengan metode konvensional. Asam laktat yang dihasilkan juga meningkat $16 \%$, yang apabila dilihat dari sekuensi DNA bakteri ternyata 
memiliki kesamaan sifat dengan L.casei yang dikodekan dengan gen LC2W_0247, LC2W_0909, LC2W_0925, LC2W_2007, LC2W_2678, serta kesamaan 174 pasang basa hingga $75 \%$ dengan $L$. jensenii yang dikodekan dengan gen LACJE0001_1464 dan HMPREF0886_1035 (Wibisono, 2012). Adanya asam laktat yang dihasilkan secara optimal, menyebabkan perubahan karakteristik dari tepung yang dihasilkan berupa naiknya viskositas, kemampuan gelasi, daya rehidrasi, dan kemudahan melarut. Kandungan nitrogen mocaf dengan penggunaan bakteri baru ternyata menurun, sehingga dapat mengurangi intensitas warna coklat pada saat pengeringan atau pemanasan.

Hasil penelitian di pendahuluan juga menunjukkan jumlah air optimum yang tepat digunakan adalah 50 persen dari total formulasi. Hasil analisa awal, dengan teknologi mocaf yang dikembangkan, beras tiruan memiliki kandungan protein 9,73 persen, lebih tinggi dibandingkan dengan beras asli yang memiliki kandungan 7,2 persen. Sementara kandungan serat beras asli hanya 0,3 persen, namun beras tiruan tersebut memiliki serat hampir 5 persen. Kandungan kadar air dalam beras tiruan sebesar 7 hingga 9 persen, yang masih di bawah ambang batas kadar air maksimal yang dipersyaratkan SNI atau BSN yaitu sebesar 13 persen. Rendahnya kadar air pada beras disebabkan oleh proses pengeringan yang memaksa air melewati titik kesetimbangannya. Dugaan masa (daya) simpan beras tiruan yang berkaitan dengan $\mathrm{A}_{\mathrm{w}}$ produk dengan $\mathrm{RH}$ udara telah menghasikan data bahwa hingga minggu ke 6 , produk tidak mengalami kenaikan kadar air, sehingga beras tiruan diduga masih aman dikonsumsi hingga minggu ke 8 . Dugaan masa simpan dengan metode yang lebih baik, serta analisa komposisi beras tiruan lebih lanjut akan dilakukan di tahun kedua. Hal yang menarik adalah kandungan karbohidrat, baik untuk beras tiruan maupun beras asli ternyata hampir sama yaitu sekitar 80 persen. Hasil analisa proksimat lainnya yang dilakukan pada beras tiruan dengan formulasi akhir adalah: 0,52 persen kadar abu dan 1,12 persen kadar lemak. Kadar abu berkaitan dengan jumlah mineral dan zat anorganik yang terkandung dalam produk, sedangkan kandungan mineral dipengaruhi oleh kondisi prapanen dan varietas ubi kayu yang digunakan sebagai bahan baku.

Hasil analisa densitas kamba beras tiruan menunjukkan hasil yang lebih tinggi dibandingkan dengan beras asli, yakni sekitar $0,58 \mathrm{~g} / \mathrm{ml}$. Pengamatan fisik yang dilakukan meliputi panjang dan diameter beras tiruan, juga menunjukkan perbedaan dengan beras asli, namun memiliki ukuran yang seragam, sesuai dengan jenis ekstruder yang digunakan. Pada penelitian awal tidak dipelajari adanya kehilangan produk (rendemen) selama proses berlangsung. Hal ini disebabkan adanya keragaman nilai rendemen dalam pembuatan beras tiruan, meliputi kadar air adonan, kecepatan masuknya adonan ke alat ekstruder, dan pemotongan produk keluaran (meskipun dilakukan secara manual, karena alat yang bersifat otomatis belum terdapat di pasaran).

Keunggulan dari beras tiruan adalah memiliki indeks glikemik pangan yang diduga rendah, hal ini akan diteliti pada tahun kedua. Indeks glikemik pangan merupakan sifat pangan yang unik dan dipengaruhi oleh banyak faktor, diantaranya jenis bahan, cara pengolahan dan karakteristik (komposisi dan sifat biokimiawi) bahan. Menurut penelitian terdahulu, sifat-sifat tersebut tidak bisa diprediksi dari satu karakter bahan saja, melainkan dari kontribusi dan saling pengaruh yang bersifat sinergism antar sifat bahan sehingga hasil akhir akan memberikan respon glikemik tertentu. Meskipun demikian, dugaan adanya indeks glikemik yang rendah dapat diketahui dari kandungan karbohidrat yang memungkinkan penyerapan dalam darah menjadi lambat. Kandungan karbohidrat dipengaruhi oleh amilosa dan amilopektin yang tersedia dalam beras tiruan. Diduga kandungan amilosa yang tinggi, menyebabkan bahan kompleks tersebut dicerna lebih lambat dibandingkan dengan amilopektin, karena amilosa merupakan polimer dari gula sederhana dengan rantai lurus, tdiak bercabang dan tidak mudah tergelatinisasi. Daya cerna pati akan dipelajari di tahun kedua baik secara in vitro maupun in vivo, sebagai data petunjuk keunggulan beras tiruan. Daya cerna pati adalah tingkat kemudahan suatu jenis pati untuk dapat dihidrolisis oleh enzim pemecah pati menjadi unitunit yang lebih sederhana. Pada umumnya, daya cerna pati dapat diberikan sebagai suatu proses pemecahan pati dan penyerapan oleh tubuh. Pemecahan dan penyerapan karbohidrat dalam tubuh terlebih dahulu harus dirubah menjadi glukosa sebagai komponen terkecil. Daya cerna pati berkaitan dengan asam dinitrosalisilat (proses yang terjadi pada saat fermentasi mocaf) yang diduga mempengaruhi struktur pati. Adapun struktur pati yang dianalisa menggunakan SEM, akan dilakukan pada tahun kedua.

Beras tiruan yang dihasilkan memiliki perbedaan yang signifikan dengan beras tiruan yang dibuat di luar negeri. Di Wahsinton, beras tiruan dengan paten terdaftar no 020.816 dapat dibuat dengan penepungan gandum (barley), pembuatan pasta dengan menambahkan air hingga 20 sampai $30 \%$ (pada kondisi suhu $32-38^{\circ} \mathrm{C}$ ), pencampuran degan mixer pada suhu $40^{\circ} \mathrm{C}$, kemudian ditekan dengan roller pada kondisi 
Agus S,Yossi W, dan Heri Warsito, Pengembangan Proses Pembuatan Beras Tiruan Berbasis Umbi Lokal Dengan Memanfaatkan Ekstruder Ulir Tunggal

vakum menggunakan mesin yang disebut cromola. Beras tersebut telah diteliti dan dibuat menggunakan teknologi nano partikel, dengan penambahan (fortifikasi) beberapa vitamin serta mineral dan bahkan ekstrak daging (Life Science Weekly, 2012). IPB memproduksi beras analog yang memiliki kualitas warna kecoklatan yang serupa dengan beras tiruan tim Politeknik Negeri Jember, namun dalam proses pembuatannya, tim IPB menggunakan mesin bertipe tween screw ekstruder dengan formulasi bahan yang sangat berbeda dengan yang dikembangkan oleh tim Politeknik Negeri Jember. Di negara berkembang lainnya, hingga saat ini teknologi pembuatan beras analog antara lain metode pembutiran atau granulasi (Yoshida et al. 1971; Kurachi 1995; Samad 2003) dan metode ekstrusi (Scella et al. 1987; Bett-Gaber et al. 2004; Moretti et al. 2005; Mishra et al. 2012). Perbedaan metode tersebut menyebabkan perbedaan bentuk akhir produk. Pada pembuatan beras tiruan menggunakan metode pembutiran beras akan memiliki bentuk bulat seperti sagu mutiara, namun pada metode ekstrusi yang dikembangkan oleh Tim Politeknik Negeri Jember memiliki bentuk produk adalah lonjong dan hampir menyerupai butir beras.

\section{KESIMPULAN DAN SARAN}

\section{KESIMPULAN}

Hasil penelitian memberikan kesimpulan

1. Beras tiruan dapat dihasilkan dengan menggunakan formulasi dari tepung jagung dan mocaf dengan proporsi perbandingan hasil penelitian dan dengan menggunakan ulir ekstruder yang telah dibuat oleh tim peneliti. Pengembangan secara komersial akan dilakukan pada tahun kedua melalui kerjasama dengan Kantor Ketahanan Pangan Kabupaten Bondowoso.

2. Hal yang paling kritis dan harus dikendalikan saat pencetakan beras tiruan adalah ketepatan suhu, kecepatan ulir dan kadar air adonan.

3. Beras tiruan memiliki karakteristik yang serupa dengan beras natif, namun masih perlu penelitian lanjutan pada tahun kedua untuk kajian karakteristik dari komposisi fisik, kimia, kajian in vitro atau in vivo serta struktur granula pati lebih lanjut menggunakan alat modern.

\section{SARAN}

Saran yang dapat diberikan adalah pola pembelajaran konsumsi beras tiruan di kabupaten diluar Kabupaten Jember dapat dilakukan dengan kebijakan pemerintah daerah setempat yang dimulai dari gerakan secara simultan dengan mengajak peran aktif warga setempat.

\section{DAFTAR PUSTAKA}

Alonso, R., E.Orue, M.J. Zalbalza, G. Grant and F. Marzo, 2000. Effect of extrusion cooking on structure and functional properties of pea and kidney bean proteins. J. Sci Food Agric 80: 397-403

Anonim, 2006. Impor Beras untuk Mengamankan Stok Nasional. http://www.depkominfo go.id.

AOAC, 1995. Official Methods of Analysis of AOAC International 6 th. AOAC International, Suite 400, Virginia, USA.

Burguess L.D. and D.W. Staenly, 1976. A possible mechanism for thermal texturization of soybean protein. Can. Inst J. of Food Science Technol. 9: 228-231.

Bjorck, I and N. Asp, 1983. The effects of extrusion cooking on nutritional value- a literature review. Journal of Food Engineering, 2:281-308

Cagampang, G.B., C.M. Perez and B.O. Juliano, 1973. A get consistency test for eating quality of rice. J. Sci. Food Agric. 24:1589-1594

Camire, M., A. Camire and K. Krumhar, 1990. Chemical and Nutritional Changes in Food during Extrusion. Critical Review in Food Science and Nutrition 29(1):3556.

Chang, Y.L., 1995. Q.S. Version 3.0. Prentice Hall, New Jersey.

Colonna, P., J. Tayeb and C. Mercier, 1989. Extrusion cooking of starch and strachy products. In Extrusion cooking. C. Mercier, P.Linko and J.M. Harper (Ed.). Am. Assoc. Cereal Chem., Inc., St. Paul, MN.

Dimyati, J.W. dan A.H. Maliyan, 1998. Penelitian dan Pengembangan Umbi-Umbian. Pusat Penelitian dan Pengembangan Tanaman Pangan, Bogor.

Fichtali J and van de Voort FR. 1989. Fundamental and practical aspects of twin screw extrusion. Cereal Food World 34(11):921-928.

Galmo, E.P., W.E. Sullevan and C.R. Canada. 1984. Engineering Economy. $7^{\text {th }}$ Mac. Pub. Co. New York.

Gautam, A. and G.S. Choudhoury, 1999. Screw configuration effects on strach breakdown during twin screw extrusion of rice flour. J. Food Process Preserv. 23(4):355-375.

Gogoi, B.K., A.J. Oswalt and G.S. Choudhury, 1996. Reverse screw element(s) and feed 
composition effects during twin-screw extrusion of rice flour and fish muscle blends. J. Food Sci 61: 590-595.

Gujska, E and K. Khan, 1991. High temperature extrusion effects on protein solubility and distribution in Navy and Pinto beans. J. Food Sci 56: 1013-1016.

Guy, R., 2003. Extrusion Cooking, Technologies and Applications. Woodhead Publishing Limited, Cambridge England.

Halick, J.V. and V.J. Kelly, 1959. Gelatinization and pasting characteristic of rice varieties as related to cooking behavior. Cereal Chem. 36: 91-98.

Harper,J. and G. Jansen, 1985. Production of nutritious precooked foods in developing counties by low-cost extrution technology. Food Rev. Int. 1(1): 27- 97

Haryanto dan Pangloli, 1991. Potensi dan Pemanfaatan Sagu. Kanisius, Yogyakarta

Hauck BW, G.R. Huber, 1989. Single screw vs twin screw extrusion. Cereal Food World 34(11):930-939.

Husodo, S.Y., dan Muchtadi 2001. Kemandirian di Bidang Pangan Kebutuhan Negara Kita. Makalah Seminar PATPI, 9-10 Oktober 2001, Semarang.

Jin, Z., F. Hsieh and H.E. Huff, 1994. Extrussion cooking of corn meal with soy fiber, salt and sugar. Cereal Chem. 75(3):227-234.

Juliano, B.O., 1971. A simplified assay for milled rice amylase.Cereal Sci. 16: 334-338

Kon, S., J.R. Wagner, R. Becker, A.N. Booth and D.J. Robbins, 1971. Optimizing nutrient availability of legume food product. $\mathbf{J}$. Food Sci. 36: 635

Kurachi, H., 1995. Process of Making Enriched Artificial Rice. United States Patent 5403606.

Li, M and T.C. Lee, 1996. Effect of extrusion temperature on solubility and molecular weight distribution of wheat flour proteins. J. Agric Food Chem 44: 763768

Mayasari, A.Y., 2007. Beras Instan dari Jagung, Singkong dan Pati Sagu Kajian Sifat Fisik dan Organoleptik. Skripsi Mahasiswa, Fakultas Teknologi Hasil Pertanian, Universitas Jember.

Mouquet, C., B. Salvignol, N. Van Hoan, J. Monvois, S. Treche, 2003. Ability of a "very low cost extruder" to produce instant infant flour at a small scale in Vietnam. Food Chem. 82: 249-255

Nadriman, 2004. Sagu Sumber Karbohidrat. http://www.bppt.go.id.
Philips, R.D., M.S. Chinnan and M.B. Kennedy, 1984. Effect of feed, moisture and barrel temperature on physical properties of extruded cow pea meal. J. Food Sci. 49:916-920

Politz, M.L., J.D. Timpa and B.P. Wasserman, 1994.Quantitave measurement of extrusion-induced starch fragmentation products in maize flour using nonqueous automaticgel-permeation

Chromatography. Cereal Chem. 71(6):532-536.

Prudencio-Ferreira S.H. and J.A.G. Areas, 1993. Protein-protein interactions in the extrusion of soya at various temperatures and moisture contents. J. Food Sci. 58:378-381

Rietz, C.A. dan J.W. Jeremiah, 1965. A guide to Selection Combination Formulation and Cooking Foods. The AVI Publishing Company vol 2, Westport Connecticut.

Sathe, S.K. and D.K. Salunkhe, 1981. Studies on trypsin and chemotrypsin inhibitory activities, hemaeglutinating activity, and sugars in the Great Northern beans (Phaseolus vulgaris L). J Food Science 46:626-629.

Somaatmadja, D., 1984. Pemanfaatan Ubi Kayu dalam Industri Pertanian. Balai Besar Penelitian dan Pengembangan Industri Hasil Pertanian, Bogor.

Syahbuddin, H., 2001. Jangan Lupa Swamsembada Pangan. http://io.ppijepang.org/article.php

Waldroup, P.W. and K.J. Smith, 1989. Animal feed uses of legumes. In: Legumes. Chemistry, Technology and Human Nutrition. R.H. Matthews (Ed). Marcel Dekker Inc, New York.

Wang, S., J. Casulli and J.M. Bouvier, 1993. Effect of dough ingredients on apparent viscosity and properties of extrudates in twin-screw extrusion cooking. Intl J. Food Sci Technol. 28(5):465-476.

Wikipedia, 2004. Jagung. http://id.Wikipedia org/wiki/jagung

Winarno, F.G., 2002. Kimia Pangan dan Gizi. PT. Gramedia Pustaka Utama, Jakarta

Yusuf, 2003. Pembuatan Beras Tiruan (Artificial Rice) dengan Bahan Baku Ubi Kayu. Jurnal Sains BPPT vol III. 